\title{
Synthesis, Molecular Structure and Characterization of Allylic Derivatives of 6-Amino-3-methyl-1,2,4-triazolo[3,4-f][1,2,4]- triazin-8(7H)-one
}

\author{
Long-Chih Hwang ${ }^{1, *}$, Shin-Yi Jane ${ }^{1}$, Hsing-Yi Lai ${ }^{1}$, Chun-Hsien Tu ${ }^{2, \dagger}$ and Gene-Hsiang Lee ${ }^{3, \dagger}$ \\ ${ }^{1}$ Faculty of Medicinal and Applied Chemistry, Kaohsiung Medical University, Kaohsiung City 80708, \\ Taiwan, ROC \\ 2 Department of Psychiatry, Longcyuan Veterans Hospital, Pingtung 912, Taiwan, ROC \\ ${ }^{3}$ Instrumentation Center, College of Science, National Taiwan University, Taipei City 106, Taiwan, \\ ROC \\ † E-mails: aromatu@mail.vhlc.gov.tw; ghlee@ntu.edu.tw
}

* Author to whom correspondence should be addressed; e-mail: lnchhw@kmu.edu.tw

Received: 31 May 2006; in revised form: 17 June 2006 / Accepted: 19 June 2006 / Published: 22 June 2006

\begin{abstract}
Allyl- (2) and 7-allyl-6-amino-3-methyl-1,2,4-triazolo[3,4-f][1,2,4]triazin$8(7 \mathrm{H})$-one (3) were obtained via the 18-crown-6-ether catalyzed room temperature reaction of 6-amino-3-methyl-1,2,4-triazolo[3,4-f][1,2,4]triazin-8(7H)-one (1) with potassium carbonate and allyl bromide in dry acetone. The structures of these two derivatives were verified by 2D-NMR measurements, including gHSQC and gHMBC measurements. The minor compound 2 may possess aromatic character. A single crystal X-ray diffraction experiment indicated that the major compound $\mathbf{3}$ crystallizes from dimethyl sulfoxide in the monoclinic space group $P 2_{1} / n$ and its molecular structure includes an attached dimethyl sulfoxide molecule, resulting in the molecular formula $\mathrm{C}_{10} \mathrm{H}_{16} \mathrm{~N}_{6} \mathrm{O}_{2} \mathrm{~S}$. Molecular structures of 3 are linked by extensive intermolecular $\mathrm{N}-\mathrm{H} \cdots \mathrm{N}$ hydrogen bonding [graph set $\mathrm{C}_{1}^{1}(7)$ ]. Each molecule is attached to the dimethyl sulfoxide oxygen via $\mathrm{N}-\mathrm{H} \cdots \mathrm{O}$ intermolecular hydrogen bonding. The structure is further stabilized by $\pi-\pi$ stacking interactions.
\end{abstract}

Keywords: 1,2,4-Triazine; 1,2,4-triazolo[3,4-f][1,2,4]triazine; aromatic molecule; X-ray crystal structure; hydrogen bonds. 


\section{Introduction}

Many aza/deaza analogues of purine have been found to display interesting biological activities. In the last decade numerous fused 1,2,4-triazines and fused 1,2,4-triazoloes have been synthesized and screened in vitro/vivo, thus revealing their varied biochemical, biological, pharmacological or cellular activities [1-19]. Recently, we have explored a ring cyclization mechanism [20,21] in connection with the preparation of the tautomeric heterobicyclic 6-amino-1,2,4-triazolo[3,4-f][1,2,4]triazin-8(7H)-one (4,8-diaza-9-deazaguanine), the isosteric isomer of guanine and additionally we have proven by X-ray crystallographic analysis $[22,23]$ that the predominant tautomeric structure of the former is the $7 \mathrm{H}$ tautomer. To our knowledge, no report describing $N$-substituted derivatives of the tautomeric structure of 6-amino-1,2,4-triazolo[3,4-f][1,2,4]triazin-8(7H)-one has appeared to date. In continuation of our studies on the synthesis of derivatives and the tautomeric structures of the 6-amino-1,2,4-triazolo[3,4$f][1,2,4]$ triazin-8(7H)-one moiety, we report in this paper the synthesis and characterization of some $\mathrm{N}$ allylated derivatives of 6-amino-3-methyl-1,2,4-triazolo[3,4-f][1,2,4]triazin-8(7H)-one (1), viz., 1allyl-6-amino-3-methyl-1,2,4-triazolo[3,4-f][1,2,4]triazin-8(7H)-one (2) and 7-allyl-6-amino-3-methyl1,2,4-triazolo[3,4-f][1,2,4]triazin-8(7H)-one (3) as potential bioactive molecules (Scheme 1). The molecular structures of $\mathbf{2}$ and $\mathbf{3}$ have been confirmed by spectral analysis, mainly their 2D-NMR. In addition, the single $\mathrm{X}$-ray crystal structural analysis of molecule $\mathbf{3}$ is also reported, which supports the conclusions reached from the interpretation of the 2D-NMR spectral data.

\section{Scheme 1}

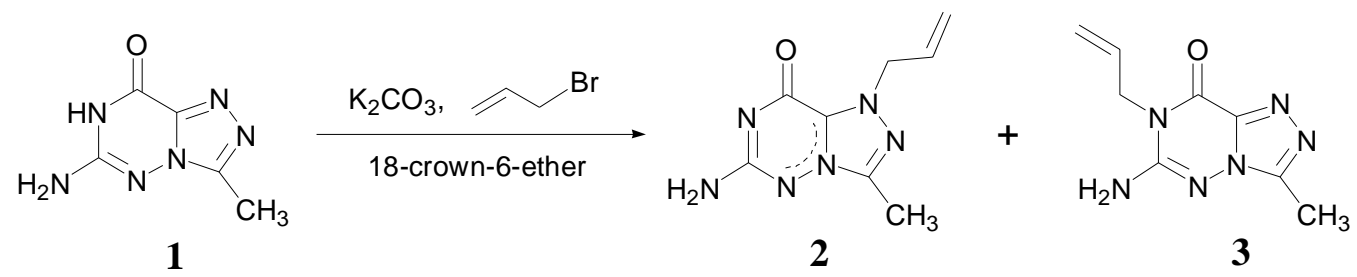

\section{Results and Discussion}

Compound 1 was reacted with potassium carbonate and allyl bromide in dry acetone at room temperature for $16 \mathrm{~h}$, under 18-crown-6-ether catalysis, to afford a 1:3 ratio of a minor product $2\left(R_{\mathrm{f}}=\right.$ $0.59)$ and a major product $3\left(R_{\mathrm{f}}=0.41\right)$ in $36 \%$ total yield. The structures of $\mathbf{1}, 2$ and 3 were completely assigned by ${ }^{1} \mathrm{H}$ - and ${ }^{13} \mathrm{C}$-NMR spectroscopy. The presence of an allyl group and eight carbon signals were observed in both compounds 2 and 3. A detailed 2D-NMR study, including gHSQC and gHMBC measurements was necessary to confirm the allylation sites of $\mathbf{2}$ and $\mathbf{3}$. The gHSQC ${ }^{1} \mathrm{H}_{-}{ }^{13} \mathrm{C}$ experiments allowed segregation of the chemical shifts of proton or carbon for the 3methyl, C-3 or allyl groups in 1, 2 and 3. The long-range gHMBC ${ }^{1} \mathrm{H}_{-}{ }^{13} \mathrm{C}$ correlations showed the attachment of the allyl group on $\mathrm{N}-1$ for structure 2 , since the methylene protons $\left(\delta_{\mathrm{H}} 5.18 \mathrm{ppm}\right)$ of this group show a ${ }^{3} J(\mathrm{H}, \mathrm{C})$ coupling to the $\mathrm{C}-8 \mathrm{a}$ carbon atom $\left(\delta_{\mathrm{C}} 133.40 \mathrm{ppm}\right)$. On the other hand, the fact that the methylene protons $\left(\delta_{\mathrm{H}} 4.52 \mathrm{ppm}\right)$ of the allyl group have a ${ }^{3} J(\mathrm{H}, \mathrm{C})$ coupling to both the C-6 $\left(\delta_{\mathrm{C}} 151.88 \mathrm{ppm}\right)$ and $\mathrm{C}-8\left(\delta_{\mathrm{C}} 153.22 \mathrm{ppm}\right)$ carbon atoms proved the attachment of the allyl group on N-7 for structure 3. 
Scheme 2 presents the numbering system of the 6 -amino-1,2,4-triazolo[3,4- $f][1,2,4]$ triazin-8(7H)one moiety and complete assignment of ${ }^{1} \mathrm{H}$ - and ${ }^{13} \mathrm{C}$-NMR signals for $\mathbf{1}, \mathbf{2}$ and $\mathbf{3}$, together with the corresponding long-range ${ }^{1} \mathrm{H}-{ }^{13} \mathrm{C}$ correlations. The $\delta$ values of ${ }^{1} \mathrm{H}$ - and ${ }^{13} \mathrm{C}-\mathrm{NMR}$ of this moiety were similar in 1 and 3. On the other hand, there were differences in the $\delta$ values of the ${ }^{1} \mathrm{H}$ - and ${ }^{13} \mathrm{C}-\mathrm{NMR}$ spectra between the $N$-1-allyl 2 and $N$-7-allyl 3; namely, the upfield shifts for 6- $\mathrm{NH}_{2}$ group and C-8a between 2 and 3 were +0.72 and +6.54 ppm, respectively. Meanwhile, the $\delta$ values of C- 6 and C-8 of 2 showed significant downfield shifts of -5.8 and -10.13 ppm, respectively, as compared to 3 . Similarly, the $\delta$ values of the methylene on the allyl group of 2 showed significant downfield shifts of -0.64 and $9.67 \mathrm{ppm}$, respectively, as compared to 3 . Taken together, molecule 2 revealed obvious differences in the NMR chemical shifts of C-6, C-8, C-8a, and the methylene on the allyl group, as compared to molecules $\mathbf{1}$ and $\mathbf{3}$. This evidence suggests that $\mathbf{2}$ may be an aromatic molecule.

\section{Scheme 2}

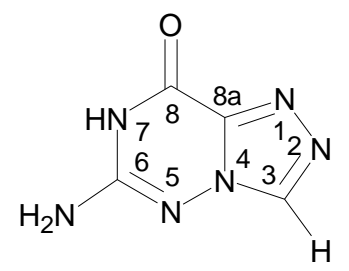

6-amino-1,2,4-triazolo[3,4- $f]$ $[1,2,4]$ triazin-8(7H)-one

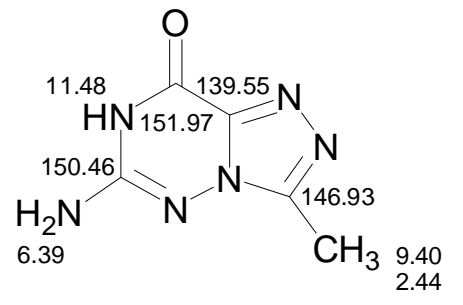

1

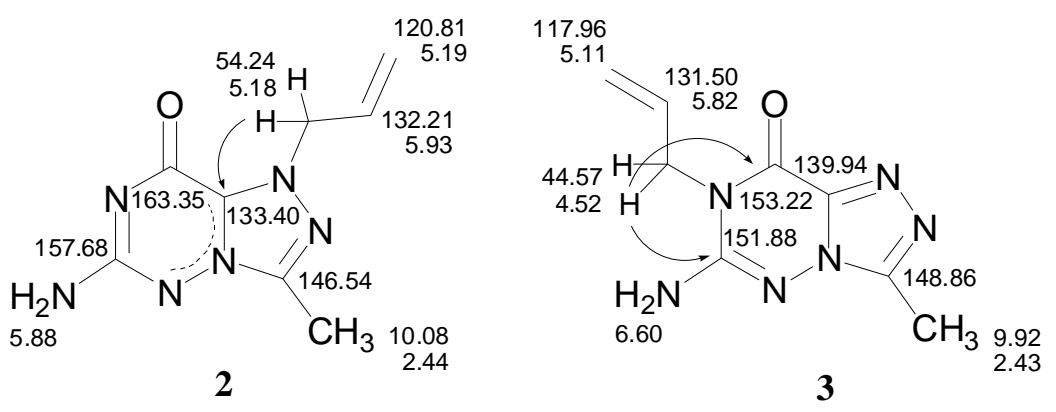

The structure of $\mathbf{3}$ was unambiguously confirmed by X-ray crystallography of its adduct with dimethyl sulfoxide (DMSO), revealing the structural framework to be the 7-allyl-6-amino-3-methyl1,2,4-triazolo[3,4-f][1,2,4]triazin-8(7H)-one connected with the oxygen of DMSO via $\mathrm{N}-\mathrm{H} \cdots \mathrm{O}$ intermolecular hydrogen bonding (Figure 1). Obviously, the allyl group is located at N(5) (i.e., N-7), which is compatible with the tautomeric 7-H proton located at N-7 in the compounds 6-amino-3-ethyl1,2,4-triazolo[3,4-f][1,2,4]triazin-8(7H)-one and 6-amino-3-benzylmercapto-1,2,4-triazolo[3,4-f]$[1,2,4]$-triazin-8(7H)-one, as previously reported by us [22,23]. The mean plane of the 1,2,4triazolo[3,4-f][1,2,4]triazine ring forms a dihedral angle of $89.14^{\circ}$ with the $\mathrm{N}(5)$-allyl group (N(5)$\mathrm{C}(5)-\mathrm{C}(6)-\mathrm{C}(7))$.

The molecular packing is shown in Figure 2. In the molecular structure of $\mathbf{3}$ the short bonds 1.306(3) $\AA$ (N(4)-C(4)), 1.316(3) $\AA$ (N(1)-C(2)) and 1.319(3) $\AA$ (N(2)-C(1)) have an appreciable double-bond character. Notably, the bond length $1.328(3) \AA \AA$ between $\mathrm{C}(4)-\mathrm{N}(6)$ is shorter than $1.355 \AA$ of $\mathrm{Car}-\mathrm{NH}_{2}$ (Nsp ${ }^{2}$ : planar) [24]. 
Figure 1. ORTEP drawing and atom labelling scheme of the compound $\mathbf{3}$ (attached to DMSO) with thermal ellipsoids drawn at the $30 \%$ probability level.

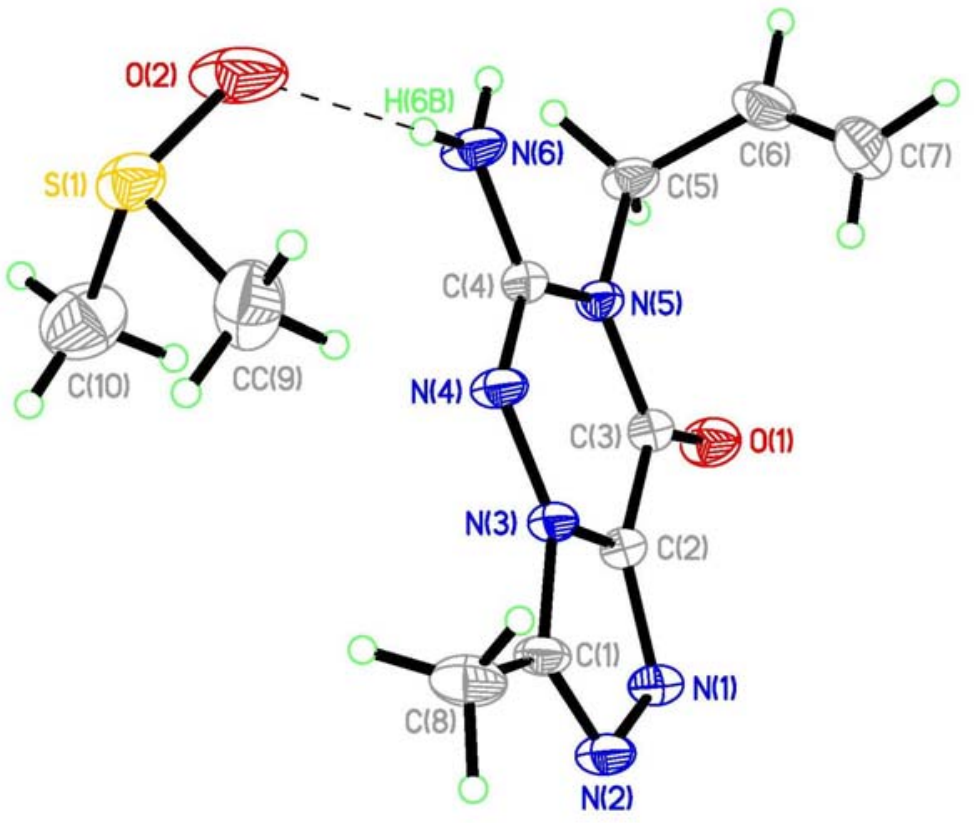

Figure 2. A perspective drawing of the packing arrangement of molecule 3 , showing (a) the molecules' direction along the $a$-view and (b) $c$-view with $\pi$ - $\pi$ stacking interactions. Dashed lines are intermolecular $\mathrm{N}-\mathrm{H} \cdots \mathrm{O}$ hydrogen bonds.

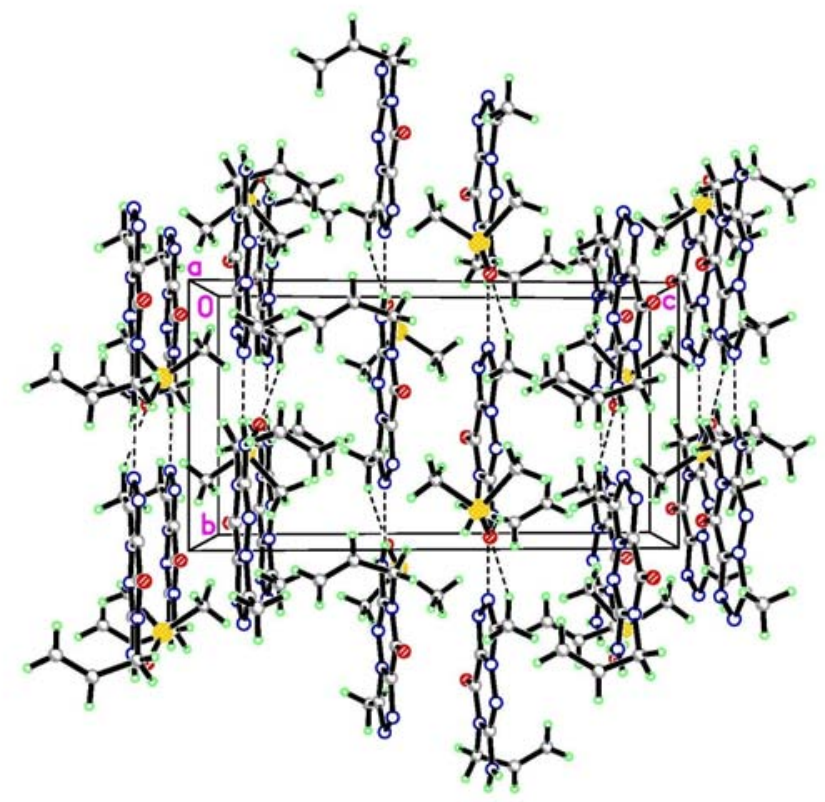

(a)

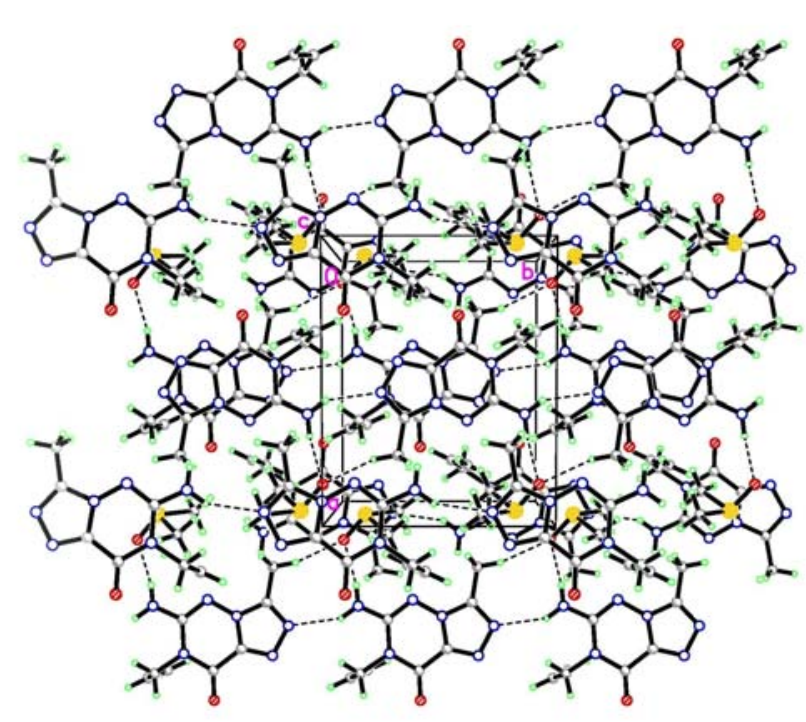

(b)

Meanwhile, the $117.78^{\circ}(19)$ value of the $\mathrm{N}(4)-\mathrm{C}(4)-\mathrm{N}(6)$ angle, close to $120^{\circ}$, confirms the $s p^{2}$ hybridization of the nitrogen atom, which implies that the 6-amino group strongly donates the unpaired electrons and resonates with the $[1,2,4]$ triazolo[3,4-f][1,2,4]triazine ring. The $\mathrm{C}(3)-\mathrm{O}(1)$ bond length (1.214(3) $\AA$ ) is shorter than the $1.240 \AA$ bond length of $C s p^{2}=\mathrm{O}(1)$ in $\delta$-lactams [24]. This may be attributed to the electron abstraction by the $\pi$-deficient heterobicyclic ring. In the structure of the 
DMSO moiety the bond lengths of 1.771 (3) (S(1)-C(9)), 1.759(3) $\AA$ (S(1)-C(10)) and 1.482(2) $\AA$ $(\mathrm{S}(1)=\mathrm{O}(2))$ are all shorter than the $1.809 \AA$ (S-C) and $1.497 \AA(\mathrm{S}=\mathrm{O})$ bond lengths in pure crystallized DMSO [24]. This is a result from the attraction of the intermolecular $\mathrm{N}-\mathrm{H} \cdots \mathrm{O}$ hydrogen bonding in the crystal structure of 3.

Analysis of the molecular packing in unit cell reveals that each molecular structure of $\mathbf{3}$ is linked by intermolecular hydrogen bonds and $\pi-\pi$ stacking interactions (Figure 3 and Table 3 ). Each molecule is linked into $\mathrm{C}_{1}^{1}(7)$ graph set association via $\mathrm{N}-\mathrm{H} \cdots \mathrm{N}$ hydrogen bond interactions (Figure 3 notation [a] and [c]). Assignment of the H-bond descriptors is based on the graph-set theory [25]. The molecular graphic was obtained using the Mercury program (version 1.4, CCDC, Cambridge, UK). Meanwhile, each molecule links with the oxygen of DMSO via $\mathrm{N}-\mathrm{H} \cdots \mathrm{O}$ hydrogen bonding ([b]). The structure is further stabilized by $\pi$ - $\pi$ stacking interactions (Figure 2: (b)), which results in the centroid $\cdots$ centroid distance (3.351 $\AA$ ) being that between the layer of $[1,2,4]$ triazolo[3,4-f][1,2,4]triazine ring.

Figure 3. A part of the crystal structure for molecule 3, showing the molecules' direction along the $a$-view with $\mathrm{x}+90^{\circ}$. Broken lines indicate the intermolecular hydrogen bonding patterns. For notation and symmetry codes see Table 1.

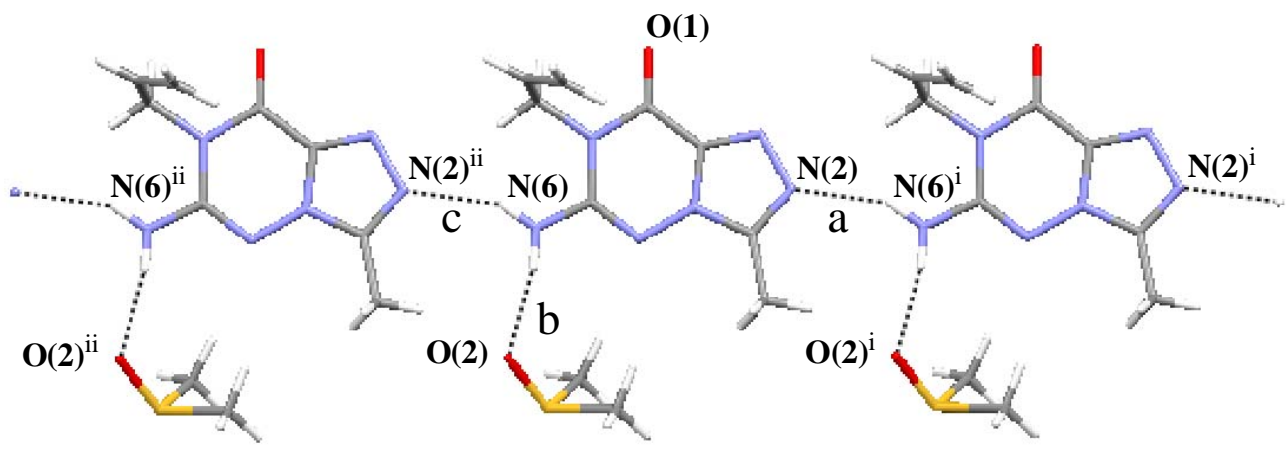

Table 1. Hydrogen bond geometry in compound 3.

\begin{tabular}{|c|c|c|c|c|c|c|}
\hline Notation & D-H $\cdots A$ & D-H (Å) & $\mathbf{H} \cdots \mathbf{A}(\AA)$ & 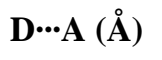 & Length-VdW & D-H $\cdots A\left({ }^{\circ}\right)$ \\
\hline $\mathrm{a}$ & $\mathrm{N}(2) \cdots \mathrm{H}(6 \mathrm{C})-\mathrm{N}(6)^{\mathrm{i}}$ & 0.860 & 2.190 & 2.978 & -0.122 & 152.27 \\
\hline b & $\mathrm{N}(6)-\mathrm{H}(6 \mathrm{~B}) \cdots \mathrm{O}(2)$ & 0.860 & 2.033 & 2.848 & -0.222 & 157.57 \\
\hline c & $\mathrm{N}(6)-\mathrm{H}(6 \mathrm{C}) \cdots \mathrm{N}(2)^{\mathrm{ii}}$ & 0.860 & 2.190 & 2.978 & -0.122 & 152.27 \\
\hline
\end{tabular}

*Note. Symmetry codes: (i) $x, 1+y, z$; (ii) $x,-1+y, z$.

\section{Conclusions}

In summary, we have reported the synthesis and molecular structure characterization of $N$-1-allyl 2 and $N$-7-allyl 3. The 2D-NMR spectral analysis allowed complete assignments of various carbons of these molecules. Obviously different $\delta$ values in ${ }^{1} \mathrm{H}$ - and ${ }^{13} \mathrm{C}-\mathrm{NMR}$ spectra between 2 and 3 were found. A single X-ray crystal structural analysis of $\mathbf{3}$ supported the evidence gathered from the NMR spectral interpretation. 


\section{General}

Melting points were measured on a YANACO micromelting point apparatus and were uncorrected. The Infrared spectra were recorded as KBr discs on a Perkin-Elmer FTIR 1650 instrument. The UVVIS spectra were measured on a GBC Cintra 6 UV-Visible spectrometer. The ${ }^{1} \mathrm{H}$ NMR and ${ }^{13} \mathrm{C}$ NMR spectra were obtained in dimethyl sulfoxide- $\mathrm{d}_{6}\left(\mathrm{DMSO}-\mathrm{d}_{6}\right)$ on a Varian Mercury-plus $400(400 \mathrm{MHz})$ spectrometer. Chemical shifts are expressed in ppm $(\delta)$ with tetramethylsilane (TMS) as an internal standard. For the assignments of signals, standard and long-range ${ }^{1} \mathrm{H}-{ }^{13} \mathrm{C}$ heteronuclear chemical shift correlation 2D-NMR experiments (gHSQC and gHMBC) were used. Thin layer chromatography (tlc) analyses were performed on silica gel plates (Merck $60 \mathrm{~F}_{254}, 0.2 \mathrm{~mm}$ thickness), and the components were detected by UV light (254 nm). Mass spectra were obtained on a Quattro VG-5022 spectrometer with an ionization potential of $70 \mathrm{eV}$. Elemental analyses were performed on a Heraeus CHN-O-Rapid elemental analyzer. All the solvents used were dried and distilled under argon prior to use.

\section{Syntheses: 6-Amino-3-methyl-1,2,4-triazolo[3,4-f][1,2,4]triazin-8(7H)-one (1)}

Compound 1 was prepared as described by Lovelette [26], m.p. $>300^{\circ} \mathrm{C}$ (from water); $\mathrm{IR}\left(\mathrm{cm}^{-1}\right)$, $v_{\max }$ : 3340, 3185, $1729(\mathrm{C}=\mathrm{O}), 1625(\mathrm{C}=\mathrm{N}), 1517,1408,1283,1131 ; \mathrm{UV}, \lambda_{\max } \mathrm{nm}(\log \varepsilon):(0.1 \mathrm{~N} \mathrm{HCl})$ 213 (4.35); ( $\left.\mathrm{H}_{2} \mathrm{O}\right) 208$ (4.56), 220 (4.56); (0.1 N NaOH) 208 (4.25), 220 (4.39); ${ }^{1} \mathrm{H}-\mathrm{NMR}, \delta$ : 2.44 (s, $\left.3 \mathrm{H}, \mathrm{CH}_{3}\right) ; 6.39$ (s, 2H, NH ); 11.48 (br s, $\left.1 \mathrm{H}, \mathrm{NH}\right) ;{ }^{13} \mathrm{C}-\mathrm{NMR}, \delta: 9.40\left(\mathrm{CH}_{3}\right), 139.55$ (C-8a), 146.93 (C-3), 150.46 (C-6), 151.97 (C-8); MS, m/z (\%): 166 (M+3 35), 138 (3), 123 (5), 111 (8), 97 (6), 91 (4), 77 (5), 69 (24), 54 (32), 43 (100). Anal. calcd for $\mathrm{C}_{5} \mathrm{H}_{6} \mathrm{~N}_{6} \mathrm{O}$ : C, 36.15\%; H, 3.64\%; N, 50.58\%. Found: C, 36.10\%; H, 3.70\%; N, 50.74\%.

1-Allyl-6-amino-3-methyl-1,2,4-triazolo[3,4-f][1,2,4]triazin-8(7H)-one (2) and 7-Allyl-6-amino-3methyl-1,2,4-triazolo[3,4-f][1,2,4]triazin-8(7H)-one (3)

A solution of $1(0.83 \mathrm{~g}, 5 \mathrm{mmol})$ in dry acetone $(30 \mathrm{~mL})$ was mixed with anhydrous potassium carbonate ( $0.69 \mathrm{~g}, 5 \mathrm{mmol})$ and a catalytic amount of 18-crown-6-ether ( $0.13 \mathrm{~g}, 0.5 \mathrm{mmol})$. Then allyl bromide ( $0.60 \mathrm{~g}, 5 \mathrm{mmol}$ ) was added and the mixture stirred at room temperature for $16 \mathrm{~h}$. The solvent was evaporated to afford a crude product which was then applied to a silica gel (230-400 mesh) column. The column was eluted with a mixture of chloroform and methanol (50:1) and the appropriate fractions were combined and evaporated.

The $R_{\mathrm{f}}$ value of the minor adduct was 0.59 (chloroform- methanol = 5:1). The residue thus obtained was recrystallized from ethanol to give $2(0.09 \mathrm{~g}, 9 \%)$ as bright white crystals, m.p. $278-279^{\circ} \mathrm{C}$; IR $\left(\mathrm{cm}^{-1}\right), v_{\max }$ : 3384, 3321, 3141, $1706(\mathrm{C}=\mathrm{O}), 1657(\mathrm{C}=\mathrm{N}), 1591,1493,1425,1315,1267,1098,969$, 919; UV, $\lambda_{\max } \mathrm{nm}(\log \varepsilon)$ : $(0.1 \mathrm{~N} \mathrm{HCl}) 217$ (4.41); ( $\left.\mathrm{H}_{2} \mathrm{O}\right) 224$ (4.66); (0.1 N NaOH) 218 (4.07); ${ }^{1} \mathrm{H}-$ NMR, $\delta: 2.44\left(3 \mathrm{H}, \mathrm{CH}_{3}\right), 5.18\left(2 \mathrm{H}, \mathrm{CH}_{2}\right), 5.19\left(2 \mathrm{H}, \mathrm{CH}=\mathrm{CH}_{2}\right), 5.93\left(1 \mathrm{H}, \mathrm{CH}=\mathrm{CH}_{2}\right), 5.88\left(2 \mathrm{H}, 3-\mathrm{NH}_{2}\right)$; ${ }^{13} \mathrm{C}-\mathrm{NMR}, \delta$ : $10.08\left(\mathrm{CH}_{3}\right), 54.24\left(\mathrm{CH}_{2}\right), 120.81\left(\mathrm{CH}=\mathrm{CH}_{2}\right), 132.21\left(\mathrm{CH}=\mathrm{CH}_{2}\right), 133.40(\mathrm{C}-8 \mathrm{a}), 146.54$ (C-3), 157.68 (C-6), 163.35 (C-8); MS, m/z (\%): 206 (M+2 20), 165 (21), 164 (100), 111 (3), 84 (2), 69 (6), 54 (4), 42 (10); Anal. calcd for $\mathrm{C}_{10} \mathrm{H}_{10} \mathrm{~N}_{4} \mathrm{O}$ : C, 46.60\%; H, 4.89\%; N, 40.76\%. Found: C, 46.72\%; H, 4.86\%; N, 40.65\%. 
The $R_{\mathrm{f}}$ value for the second (major) product was 0.41 (chloroform-methanol $=5: 1$ ). The residue thus obtained was recrystallized from ethanol to give $3(0.28 \mathrm{~g}, 27 \%)$ as bright white crystals, m.p. 260-261 ${ }^{\circ} \mathrm{C}$; IR $\left(\mathrm{cm}^{-1}\right), v_{\max }$ : 3383, 3321, 3141, $1706(\mathrm{C}=\mathrm{O}), 1658(\mathrm{C}=\mathrm{N}), 1591,1493,1426,1315$, 1267, 1104, 967, 920; UV, $\lambda_{\max } \mathrm{nm}(\log \varepsilon)$ : (0.1 N HCl) 208 (4.66), 213 (4.66), 218 (4.66); ( $\left.\mathrm{H}_{2} \mathrm{O}\right) 220$ (4.41); (0.1 N NaOH) 218 (4.10); ${ }^{1} \mathrm{H}-\mathrm{NMR}, \delta: 2.43\left(3 \mathrm{H}, \mathrm{CH}_{3}\right), 4.52\left(2 \mathrm{H}, \mathrm{CH}_{2}\right), 5.11\left(2 \mathrm{H}, \mathrm{CH}=\mathrm{CH}_{2}\right)$, $5.82\left(1 \mathrm{H}, \mathrm{CH}=\mathrm{CH}_{2}\right), 6.60\left(2 \mathrm{H}, 3-\mathrm{NH}_{2}\right) ;{ }^{13} \mathrm{C}-\mathrm{NMR}, \delta: 9.92\left(\mathrm{CH}_{3}\right), 44.57\left(\mathrm{CH}_{2}\right), 117.96\left(\mathrm{CH}=\mathrm{CH}_{2}\right)$, $131.50\left(\mathrm{CH}=\mathrm{CH}_{2}\right), 139.94$ (C-8a), 148.86 (C-3), 151.88 (C-6), 153.22 (C-8); MS, m/z (\%): 206 (M+, 100), 191 (71), 177 (8), 165 (17), 164 (35), 151 (10), 135 (13), 123 (6), 111 (6), 96 (5), 84 (7), 69 (10), 54 (15); Anal. calcd for $\mathrm{C}_{10} \mathrm{H}_{10} \mathrm{~N}_{4} \mathrm{O}$ : C, 46.60\%; H, 4.89\%; N\%, 40.76. Found: C, 46.60\%; H, 4.93\%; N, $40.70 \%$.

Table 2. Crystal and experimental data for compound 3.

\begin{tabular}{|l|l|}
\hline Formula & $\mathrm{C}_{10} \mathrm{H}_{16} \mathrm{~N}_{6} \mathrm{O}_{2} \mathrm{~S}$ \\
Formula weight & 284.35 \\
Crystal system & Monoclinic \\
Space group & $P 2_{1} / n$ \\
Unit-cell dimensions $(\AA)$ & $a=10.4850(6)$ \\
& $b=8.4409(5)$ \\
& $c=15.5152(9)$ \\
& $\beta=95.963(1)^{\circ}$ \\
Unit-cell volume, $V\left(\AA^{3}\right)$ & $1365.71(14)$ \\
Formula per unit cell, $Z$ & 4 \\
$D_{\text {calcd }}$ (g/cm $\left.{ }^{3}\right)$ & 1.383 \\
Absorption coefficient, $\mu\left(\mathrm{mm}^{-1}\right)$ & 0.246 \\
$F(000)$ & 600 \\
Crystal size (mm) & $0.36 \times 0.25 \times 0.08$ \\
Index ranges & $-13 \leq h \leq 13$ \\
& $-10 \leq k \leq 10$ \\
& $-20 \leq l \leq 20$ \\
Max. and min. transmission & 0.9806 and 0.9167 \\
Independent reflections & $3133\left(R_{\text {int }}=0.0480\right)$ \\
Reflections/restraints/parameters & $3133 / 0 / 175$ \\
Final R indices $[I>2 \sigma(I)]$ & $R_{1}=0.0590, w R_{2}=0.1371$ \\
$R$ indices (all data) & $R_{1}=0.0736, w R_{2}=0.1454$ \\
Goodness-of-fit on $F^{2}$ & 1.078 \\
Max. shift/error & 0.000 \\
\hline
\end{tabular}

\section{$X$-ray techniques}

X-ray quality crystals of compound 3 were obtained by crystallization from dimethyl sulfoxide at room temperature. A summary of the crystallographic data and details of the structure refinements is listed in Table 2. The data was collected on a BRUKER SMART ApexCCD diffractometer with a graphite-monochromated MoK $\alpha$ radiation $(\lambda=0.71073 \AA$ ) at 295(2) K. The crystal structure has been 
deposited at the Cambridge Crystallographic Data Centre [27]. A total of 13191 reflections and 3133 independent reflections $\left(R_{\text {int }}=0.0480\right)$ were collected within the range of $2.24<\theta<27.50^{\circ}$ by using the $\omega$ scan technique, of which 2535 observed reflections with $I>2 \sigma(I)$ were used in the structural analysis. The crystal structure was solved by direct methods using SHELXS-97 [28] and refined by full-matrix least-squares methods on $F^{2}$ using SHELXL-97 [29]. All non-H atoms were refined anisotropically. The hydrogen atoms were placed geometrically and refined as riding. The final cycle of full-matrix least-squares refinement gave $R_{1}=0.0416, w R_{2}=0.1142\left(w=1 /\left[\sigma^{2}\left(F_{o}^{2}\right)+(0.0584 P)^{2}+\right.\right.$ 0.7097P], where $\left.P=\left(F_{o}^{2}+2 F_{c}^{2}\right) / 3\right) . S=1.078$ and $(\Delta / \sigma)_{\max }=0.000$. The maximum peak on the final difference Fourier map is 0.321 and the minimum peak -0.319 e $\AA^{-3}$.

\section{Acknowledgements}

The authors would like to thank the National Science Council, Republic of China, for support under grant NSC 90-2113-M-037-015.

\section{References and Notes}

1. Pomarnacka, E. Acta Pol. Pharm. 1998, 55, 481.

2. Abdel-Rahman, R. M.; Morsy, J. M.; Hanafy, F.; Amene, H. A. Pharmazie 1999, 54, 347.

3. Abdel-Rahman, R. M.; Morsy, J. M.; El-Edfawy, S.; Amene, H. A. Pharmazie 1999, 54, 667.

4. Abdel-Rahman, R. M. Pharmazie 2001, 56, 18.

5. Abdel-Rahman, R. M. Pharmazie 2001, 56, 275.

6. El-Gendy, Z.; Morsy, J. M.; Allimony, H. A.; Ali, W. R.; Abdel-Rahman, R. M. Pharmazie 2001, 56, 376.

7. Holla, B. S.; Rao, B. S.; Gonsalves, R.; Sarojini, B. K.; Shridhara, K. Farmaco 2002, 57, 693.

8. Habib, N. S.; Soliman, R.; Ismail, K.; Hassan, A. M.; Sarg, M. T. Boll. Chim. Farm. 2003, 142, 396.

9. Iwashita, A.; Maemoto, T.; Nakada, H.; Shima, I.; Matsuoka, N.; Hisajima, H. J. Pharmacol. Exp. Ther. 2003, 307, 961.

10. Guertin, K. R.; Setti, L. Qi. L.; Dunsdon, R. M.; Dymock, B. W.; Jones, P. S.; Overton, H.; Taylor, M.; Williams, G.; Sergi, J. A.; Wang, K.; Peng, Y.; Renzetti, M.; Boyce, R.; Falcioni, F.; Garippa, R.; Olivier, A. R. Bioorg. Med. Chem. Lett. 2003, 13, 2895.

11. Hunt, J. T.; Mitt, T.; Borzilleri, R.; Gullo-Brown, J.; Fargnoli, J.; Fink, B.; Han, W. C.; Mortillo, S.; Vite, G.; Wautlet, B.; Wong, T.; Yu, C.; Zheng, X.; Bhide, R. J. Med. Chem. 2004, 47, 4054.

12. Chambers, M. S.; Atack, J. R.; Carling, R. W; Collinson, N.; Cook, S. M.; Dawson, G. R.; Ferris, P.; Hobbs, S. C.; O'Connor, D.; Marshall, G.; Rycroft, W.; Macleod, A. M. J. Med. Chem. 2004, 47, 5829.

13. Borzilleri, R. M.; Cai, Z. W.; Ellis, C.; Fargnoli, J.; Fura, A.; Gerhardt, T.; Goyal, B.; Hunt, J. T.; Mortillo, S.; Qian, L.; Tokarski, J.; Vyas V.; Wautlet, B.; Zheng, X.; Bhide, R. S. Bioorg. Med. Chem. Lett. 2005, 15, 1429. 
14. Borzilleri, R. M.; Zheng, X.; Qian, L.; Ellis, C.; Cai, Z. W.; Wautlet, B. S.; Mortillo, S.; Jeyaseelan, R. Sr.; Kukral, D. W.; Fura, A.; Kamath, A.; Vyas, V.; Tokarski, J. S.; Barrish, J. C.; Hunt, J. T.; Lombardo, L. J.; Fargnoli, J.; Bhide, R. S. J. Med. Chem. 2005, 48, 3991.

15. Fink, B. E.; Vite, G. D.; Mastalerz, H.; Kadow, J. F.; Kim, S. H.; Leavitt, K. J.; Du, K.; Crews, D.; Mitt, T.; Wong, T. W.; Hunt, J. T.; Vyas, D. M.; Tokarski, J. S. Bioorg. Med. Chem. Lett. 2005, 15, 4774.

16. Sztanke, K. Acta Pol. Pharm. 2005, 62, 221.

17. Jones, P.; Atack, J. R.; Braun, M. P.; Cato, B. P.; Chambers, M. S.; O'Connor, D.; Cook, S. M.; Hobbs, S. C.; Maxey, R.; Szekeres, H. J.; Szeto, N.; Wafford, K. A.; MacLeod, A. M. Bioorg. Med. Chem. Lett. 2006, 16, 872.

18. Gupta, R.; Gupta, A. K.; Paul, S.; Kachroo, P. L. Indian J. Chem. 1998, 37B, 1211.

19. Hiremath, S. P.; Ullagaddi, A.; Shivaramayya, K.; Purohit, M.G. Indian J. Heterocycl. Chem. 1999, 3, 145.

20. Hwang, L. C.; Wu, R. R.; Tu, C. H. J. Heterocycl. Chem. 2005, 42, 851.

21. Hwang, L. C.; Tu, C. H.; Wang, J. H. J. Heterocycl. Chem. 2006, in press.

22. Hwang, L. C.; Tu, C. H.; Wang, J. H.; Lee, G. H.; Wang, Y. Anal. Sci. 2002, 18, 853.

23. Hwang, L. C.; Tu, C. H.; Wang, J. H.; Lee, G. H. Molecules, 2006, 11, 169.

24. Lide, D. R. CRC Handbook of Chemistry and Physics; 80th ed.; CRC Press LLC: Boca Raton, FL, 1999-2000; Section 9, pp. 1-14.

25. Bernstein, J.; Davis, R. E.; Shimoni, L.; Chang, N. L. Angew. Chem. Int. Ed. Engl. 1995, 34, 1555.

26. Lovelette, C. A. J. Heterocycl. Chem. 1979, 16, 555.

27. CCDC 608157 contains the supplementary crystallographic data for this paper. These data can be obtained free of charge via www.ccdc.cam.ac.uk/conts/retrieving.html (or from the CCDC, 12 Union Road, Cambridge CB2 1EZ, UK; fax: +44 1223 336033; e-mail: deposit@ccdc.cam.ac.uk).

28. Sheldrick, G. M. SHELXS-97, Program for the Solution of Crystal Structure; Univ. of Göttingen: Göttingen, Germany, 1990.

29. Sheldrick, G. M. SHELXL-97, Program for the Refinement of Crystal Structure; Univ. of Göttingen: Göttingen, Germany, 1997.

Sample Availability: Samples of the compounds mentioned are available from the authors.

(C) 2006 by MDPI (http://www.mdpi.org). Reproduction is permitted for noncommercial purposes. 